\title{
42. THE GEOCHEMISTRY OF OCEANIC CRUST AT THE ONSET OF RIFTING IN THE INDIAN OCEAN ${ }^{1}$
}

\author{
John N. Ludden ${ }^{2}$ and B. Dionne ${ }^{2}$
}

\begin{abstract}
Indian Ocean crust formed at Sites 765 and 766 is geochemically comparable to that presently forming in the Red Sea. In both cases, we interpret the crust as reflecting high degrees of mantle melting that are associated with an enhanced thermal gradient below recently rifted continental lithosphere. Asthenospheric melts formed in this environment are rich in $\mathrm{CaO}$ and $\mathrm{FeO}$, poor in $\mathrm{Na}_{2} \mathrm{O}$ and $\mathrm{Al}_{2} \mathrm{O}_{3}$, and characterized by depleted rare earth element (REE) profiles $\left([\mathrm{La} / \mathrm{Sm}]_{n}\right.$ approximately $0.5-0.6)$. Both the Red Sea basalts and the basalts at Sites 765 and 766 are distinct from those erupted at the present Mid-Indian Ocean Ridge.

The isotope characteristics of the Site 765 basalts define a geochemical signature similar to that of the present-day Mid-Indian Ocean Ridge basalts (MIORB). The Indian Ocean mantle domain is distinct from that of the Atlantic and Pacific oceans, and this distinction has persisted since Jurassic time, when the Site 765 oceanic crust was formed.
\end{abstract}

\section{INTRODUCTION}

Largely because of the difficulties when sampling oceanic basement at continental margins, the composition of oceanic crust at the onset of oceanic rifting is poorly constrained. Rifted margins are commonly covered by a thick sequence of sediments related to subsidence on a passive margin that followed the initial formation of oceanic crust, and thus penetration of the entire sediment section by drilling often is impossible. Where true oceanic crust was sampled at the oceanic margins during the Deep Sea Drilling Project (DSDP), drilling was continued until bit destruction, and usually only a few meters of basement were recovered. A notable exception for DSDP was at Sites 416 and 417 in Cretaceous crust in the west-central Atlantic Ocean. One of the prime objectives of Leg 123 was to obtain a sedimentary section and oceanic basement from the oldest (Late Jurassic) Indian Ocean crust in the Argo Abyssal Plain off the northwestern Australian margin. The low sedimentation rates on this margin since its formation in the Latest Jurassic provided a compact 930-m sedimentary section. This enabled Leg 123 scientists at Site 765 to complete high-resolution biostratigraphic and sedimentological studies of the post-rifting history of the northwestern Australian margin, in addition to relatively easy penetration of $270 \mathrm{~m}$ of basement. A second hole (Site 766) was drilled into younger oceanic crust (Early Cretaceous) on the continental margin adjacent to the Gascoyne Abyssal Plain. In this case, the basement was characterized as transitional in acoustic characteristics (see Buffler et al., this volume). In contrast to Site 765, where true oceanic basement was sampled, the acoustic basement at Site 766 comprised a suite of intrusions that had been interbedded with clastic sediments. The tholeiitic magmas that formed the intrusions at Site 766 may overlie highly attenuated northwestern Australian margin basement.

The scientific importance of sampling oceanic crust at the onset of rifting relates to the thermal properties of the mantle at this stage in the formation of an oceanic basin. Given the high heat flux that might characterize a thermal anomaly associated

\footnotetext{
${ }^{1}$ Gradstein, F. M., Ludden, J. N., et al., 1992. Proc. ODP, Sci. Results, 123: College Station, TX (Ocean Drilling Program).

2 Terrestrial Magmatism Research Group and Département de Géologie, Université de Montréal, Montréal, CP 6128 “A," Canada, H3C 3J7.
}

with continental break-up (White and McKenzie, 1989; McKenzie and Bickle, 1988; Campbell and Griffiths, 1990), basalts that erupted in this environment should reflect a higher extent of mantle melting than those that erupted at a mid-ocean ridge axis in a mature ocean basin. For a mid-ocean ridge basalt (MORB) mantle of relatively constant composition, the greater extent of melting should be reflected in high $\mathrm{CaO}$ contents relative to $\mathrm{Na}_{2} \mathrm{O}$ and higher total-FeO contents (Dick and Fisher, 1984; Klein and Langmuir, 1987, 1989). Although variations in trace elements in MORB are greater than for major oxides, increases in the amount of melting (or two-stage melting) should result in higher chondrite-normalized REE depletion of $(\mathrm{La} / \mathrm{Sm})_{n}$ and $\mathrm{Zr} / \mathrm{Nb}$. While basalts that erupted at the present-day ridge axes do show a range in compositions, which may reflect variable amounts of mantle melting (i.e., Dick and Fisher and Klein and Langmuir, op. cit.), basalts that erupted at a rifted continental margin should reflect a greater extent of mantle melting as a result of the higher heat flux at the onset of oceanic crust formation (i.e., White and McKenzie, 1989; McKenzie and Bickle, 1988). This conclusion is supported by Keen et al. (1990), who correlated basement compositions for old oceanic crust (including Site 765) with water depths, based on seismic backtracking calculations from passive margin subsidence curves. In all cases, the implied basement thickness, extrapolated from water depths and correlated with the degree of melting (Klein and Langmuir, 1987), is greater than that of the average of today's ridge axes.

In the Indian Ocean, ocean basement has been sampled near the continental margin in two places: (1) the Argo Abyssal Plain at Sites 765 and 766 (Leg 123), which are located on Jurassic ocean crust formed at the onset of rifting of the Indian Ocean, and (2) the Red Sea, where active rifting is forming new Indian Ocean crust that has been sampled by dredging and submersibles (Eissen et al., 1989). In this chapter, the geochemistry of basalts that erupted in these two regions is compared with that of basalts that erupted at the Mid-Indian Ocean Ridge. While the database is limited, the Indian Ocean does provide two sites where fresh basalts may be sampled from oceanic crust near a continental margin zone of extension.

Basalts that erupted along the present-day Indian Ocean ridges are characterized by isotope compositions that are distinct from those that erupted along the Atlantic and Pacific mid-oceanic ridge axes (Ito et al., 1987; Klein et al., 1988). These differences are largely identifiable in terms of lower ${ }^{206} \mathrm{~Pb} /{ }^{204} \mathrm{~Pb}$ ratios at 
equivalent ${ }^{87} \mathrm{Sr} /{ }^{86} \mathrm{Sr}$ and ${ }^{143} \mathrm{Nd} /{ }^{144} \mathrm{Nd}$ values and reflect a higher "Dupal" component in Indian Ocean MORBs (Dupré and Allègre, 1983; Hart, 1984; Hamelin et al., 1985). The longevity of these geochemical characteristics has been addressed by isotope analyses in fresh glass samples from Site 765 ; these results have important consequences for Indian Ocean tectonics and mantle dynamics.

\section{VOLCANISM ON THE NORTHWESTERN AUSTRALIAN MARGIN}

\section{Northwestern Australian Continental Margin}

Seaward-dipping reflectors, which are interpreted as lava flows, have been reported for this margin (Mutter et al., 1988) and are cited as evidence that this was a volcanically active margin when it was rifted. A series of plateaus (the Scott Plateau, the Joey Rise on the Exmouth Plateau, the Wallaby Plateau, the Naturaliste Plateau, and the Zenith Seamount, identified in Fig. 1) probably reflect thick accumulations of volcanic rocks (Veevers and Cotterill, 1978; White and McKenzie, 1989). Although an extended history of Triassic-Jurassic rifting and subsidence prior to breakup existed, White and McKenzie (1989) argued that the final episode of break-up occurred in response to a thermal plume that caused the widespread volcanism now represented in these plateaus. This event was coincident with the uplift of the margin and the formation of an erosional unconformity on the Exmouth Plateau (von Rad and Exon, 1983). The thickest assemblage of volcanic rocks on the continental margin that represents this event has been sampled in the Wallaby Plateau (von Stackelberg et al., 1980). Geochemical data from von Stackleberg et al. (1980), recent analyses performed by the authors, and analyses of bentonite horizons on the Exmouth Plateau (Thurow and von Rad, this volume) indicate that these volcanic rocks are alkaline and subal- kaline basalts and rhyolites. The oldest samples, alkaline rhyolites that are underlying Jurassic carbonates in the Wombat Plateau, have been dated by K/Ar at 213 to $192 \mathrm{Ma}$ and may reflect volcanism in response to passive rifting of the margin. The major phase of rifting of the margin occurred between approximately $160 \mathrm{Ma}$ (Site 765) and $130 \mathrm{Ma}$ (Site 766). K/Ar dates from the Scott Plateau of 128 to $132 \mathrm{Ma}$ (von Stackleberg et al., 1980) may reflect the peak of the volcanism that is associated with rifting of the margin. However, $\mathrm{K} / \mathrm{Ar}$ ages as young as 83 to $89 \mathrm{Ma}$ (von Stackleberg et al., 1980) from the Wallaby Plateau must reflect (1) continued volcanism that is associated with rifting and (2) possible migration of this volcanism toward the west in response to the opening of the Gascoyne and Cuvier abyssal plains.

\section{Site 765}

The locations of Sites 765 and 766 are shown in Figure 2. Seismic studies at Site 765 indicate that this site is clearly in oceanic basement and is less than $75 \mathrm{~km}$ oceanward of a prominant magnetic anomaly that represents the ocean/continent boundary (Veevers et al., 1985). A reevaluation of the magnetic lineations in the Argo Abyssal Plain (Sager et al., this volume) places Site 765 between marine magnetic anomalies 25 and 26, corresponding to lower Valanginian to Hauterivian (about $160 \mathrm{Ma}$ ). These results are inconsistent with the biostratigraphic ages, for which a maximum age of upper Valenginian is represented (McMinn et al., this volume; Kaminski et al., this volume). These discrepancies may reflect erosion of the sediments directly overlying basement, patchy sedimentation, or inconsistencies during calibration of the marine magnetic anomalies. Radiometric dates for the basement indicate ages of approximatively $155 \mathrm{Ma}$ (Ludden, this volume).

At Site 765 , Holes $765 \mathrm{C}$ and 765D penetrated 28 and $271 \mathrm{~m}$ into volcanic basement, respectively. Twenty-two volcanic units

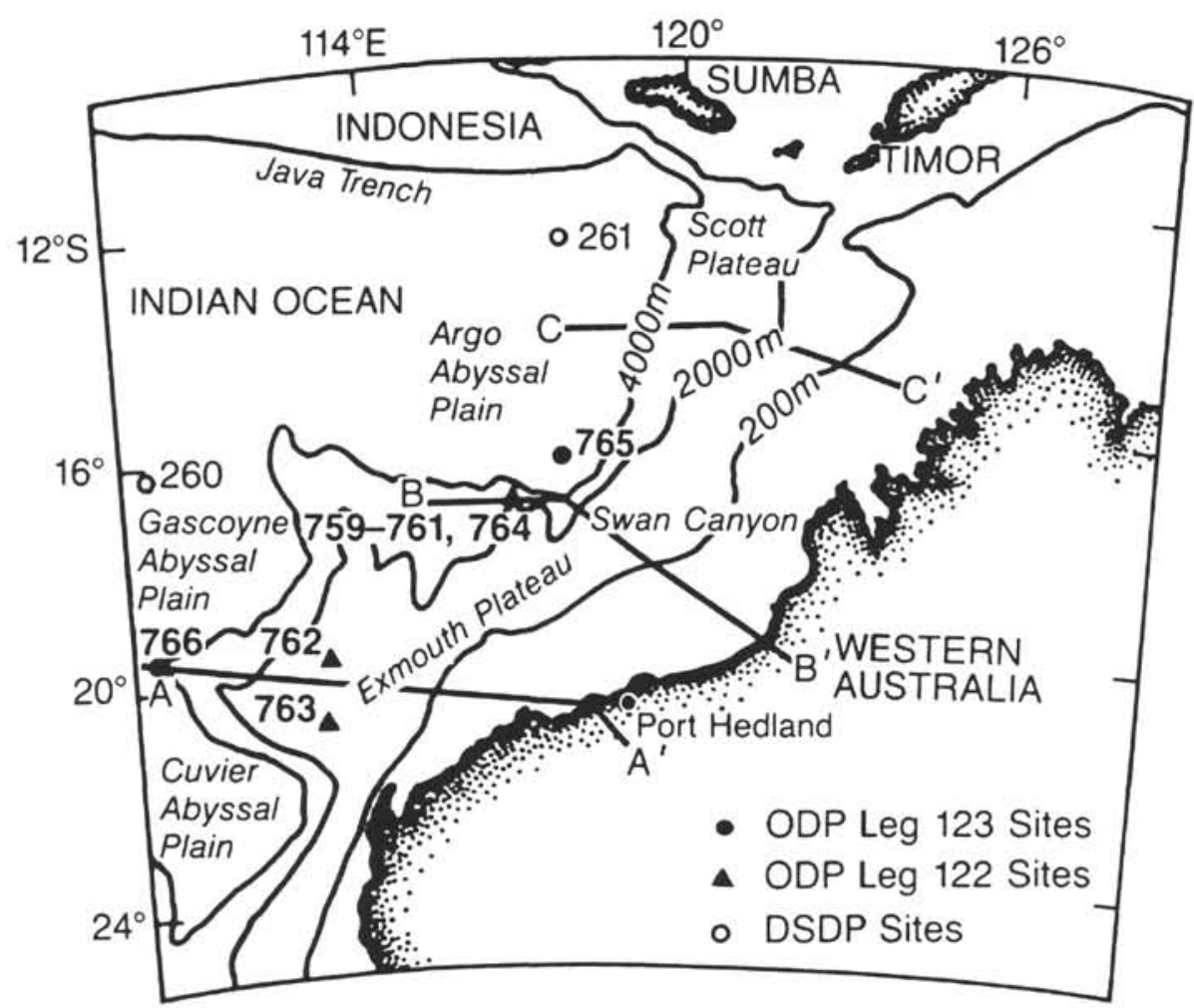

Figure 1. Location of Sites 765 and 766 (Leg 123) and Sites 759 through 764 (Leg 122) in the Argo and Gascoyne abyssal plains. 


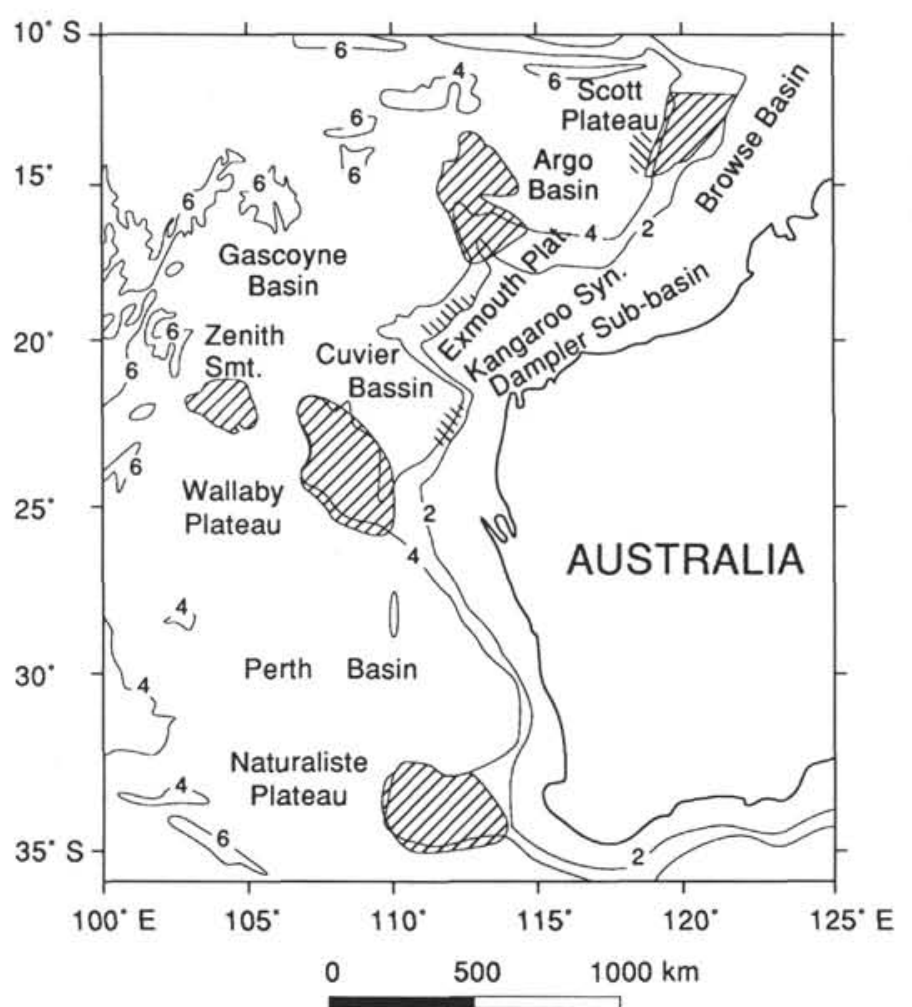

Figure 2. Volcanicity on the west Australian margin. Modified from White and McKenzie (1989). Shaded areas represent possible volcanic plateaus. Radiometric ages for the volcanic events are given in the text.

were distinguished on the basis of lithological and geochemical variations. The main lithologies recovered were pillow basalt $(54 \%)$, massive basalt $(28 \%)$, diabase $(4 \%)$, autoclastic breccia $(6 \%)$, and tectonically brecciated pillow basalt $(8 \%)$ (Ludden, Gradstein, et al., 1990). Despite the section's being one of the oldest representatives of oceanic basement cored by either ODP or DSDP, rock preservation in it is excellent. Fresh glass is present in pillow margins and within hyaloclastite breccia. Low-temperature alteration is not pervasive and is reflected in well-defined zones of oxyhydroxide and smectite precipitation that extend into the basalts from celadonite and calcite-rich veins (Gillis et al., this volume). Generally, the basalt samples taken at 3 to $4 \mathrm{~cm}$ from the low-temperature alteration zones are unaltered or only mildly altered.

Although geochemical data indicate that the lavas are typical, although somewhat evolved, MORB tholeiites, the phenocryst assemblage is atypical for MORBs (Ishiwatari, this volume). The lavas are dominantly aphyric or sparsely phyric, with rare samples having up to $10 \%$ phenocrysts. Plagioclase is the dominant phenocryst, while clinopyroxene is the only mafic member in many lavas. Olivine, when observed, has been highly altered and is xenocrystic (Ishiwatari, this volume). In the upper $50 \mathrm{~m}$ of basalt, frequent xenocryst clots of calcic plagioclase and clinopyroxene occur.

\section{Site 766}

Site 766 is located at the foot of the western escarpment of the Exmouth Plateau, facing the Gascoyne Abyssal Plain in a water depth of $4008 \mathrm{~m}$ (Fig. 1). This site is on the geophysical continent/ocean boundary limit of the most eastward seafloor segment of the Gascoyne Abyssal Plain. The Cape Range Fracture Zone that separates the Gascoyne Abyssal Plain from the Cuvier Abys- sal Plain to the south extends in a southeast-northwest direction slightly south of the site location. Geophysical investigations (Buffler et al., this volume; Ludden, Gradstein, et al., 1990) indicate that the site is located on transitional ocean crust (i.e., seismic velocities between those of continental basement and those of oceanic basement). The igneous units at Site 766 were encountered below $458 \mathrm{~m}$ of sediment. Because of the inclined nature of the contact and the baking of the sediments, the first basalt drilled was interpreted as an intrusive sheet (Ishiwatari, this volume). This unit was followed by an $8-\mathrm{m}$ interlayered sequence of 1- to $1.5-\mathrm{m}$-thick intrusions and dark green to dark gray siltstone. Below this sequence, coring recovered $60 \mathrm{~m}$ of diabase, again interpreted as a thick intrusion. Drilling was terminated while still within this intrusion; thus, Leg 123 scientists were unable to confirm the continuity of these intrusions with volcanic basement. The most reasonable interpretation for this site is that it is located at the outermost limit of the continent/ocean boundary and represents contemporaneous intrusion and sedimentation during the final stages of rifting of the northwestern Australian continental margin. While the low $\mathrm{K}_{2} \mathrm{O}$ contents of these intrusions argue against contamination by continental crust or synrift sediments, one cannot discount the possiblity that Site 766 is underlain by thinned continental basement.

\section{GEOCHEMISTRY OF VOLCANIC ROCKS AT SITES 765 AND 766}

\section{Analytical Techniques}

New geochemical data for the REEs, Th, U, Hf, Ta, and Sc, and for isotopes from glass separates (Site 765 only) are given in Tables 1 and 2, respectively. Whole-rock samples were crushed on board the JOIDES Resolution in a WC grinding vessel. The data and analytical uncertainty for the major elements and for the trace elements, $\mathrm{Nb}, \mathrm{Zr}$ and $\mathrm{Y}$, were presented in Ludden, Gradstein, et al. (1990) and were obtained by X-ray fluorescence (XRF) on board the JOIDES Resolution. The shipboard XRF data were verified by DCP and INAA analyses, and the REE data were cross calibrated between the Lamont-Doherty DCP laboratory and the Université de Montréal geochemical laboratories (see Plank and Ludden, this volume). The REEs, Th, U, Hf, Ta, and Sc, were determined at the Université de Montréal by INAA using rock powders. The samples were irradiated for $2 \mathrm{hr}$ in a Slowpoke II reactor at a constant neutron flux of $2 \times 10^{12} \mathrm{n} / \mathrm{cm}^{2} / \mathrm{s}$ and counted over a 7- to 60-day period after irradiation using two Ge detectors having a resolution of 0.6 and $1.2 \mathrm{KeV}$ at $122 \mathrm{KeV}$ and $1.33 \mathrm{MeV}$, respectively. The analytical precision for $\mathrm{La}, \mathrm{Sm}, \mathrm{Eu}, \mathrm{Yb}$, and $\mathrm{Sc}$ is $<5 \%$ and that for $\mathrm{Ce}, \mathrm{Nd}, \mathrm{Ho}, \mathrm{Tb}, \mathrm{Lu}, \mathrm{Ta}, \mathrm{Hf}$, Th, and $\mathrm{U}$ is between $5 \%$ and $10 \%$.

For each of three samples, $100 \mathrm{mg}$ of fresh glass that had been broken into 1-mm-sized fragments in an agate mortar was selected under a binocular microscope to be free of inclusions, vesicles, microphenocrysts, and altered glass. The glass separates for $\mathrm{Sr}-$ isotope analyses were leached in $2.5 \mathrm{~N} \mathrm{HCl}$ and analyzed using an NBS 12-in. mass-spectrometer at the Université de Montréal. Dissolution and separation of $\mathrm{Sr}$ were performed using the standard procedure of Hart and Brooks (1977), and ${ }^{87} \mathrm{Sr} /{ }^{86} \mathrm{Sr}$ ratios were normalized to the Eimer \& Amend standard value of 0.70800 . Samples analyzed for $\mathrm{Pb}$-isotopes and $\mathrm{Pb} / \mathrm{U}$ determination were washed with "two bottle" distilled $\mathrm{H}_{2} \mathrm{O}$, followed by "two bottle" distilled methanol and then analyzed following the technique of Mànhes et al. (1978) at the Université du Québec à Montréal. Because of the need to conserve glass separates for future research (ICP-MS in progress) and because of the limited amount of high-purity samples available, the $\mathrm{Nd}$-isotopes, determined at the University of Alberta, were conducted on leached whole-rock 
Table 1. INAA analyses of Sites 765 and 766 basalt.

\begin{tabular}{|c|c|c|c|c|c|c|c|c|c|c|c|c|c|c|c|c|}
\hline Hole & $765 \mathrm{C}$ & $765 \mathrm{D}$ & $765 \mathrm{D}$ & $765 \mathrm{D}$ & $765 \mathrm{D}$ & $765 \mathrm{D}$ & $765 \mathrm{D}$ & $765 \mathrm{D}$ & $765 \mathrm{D}$ & $765 \mathrm{D}$ & $765 \mathrm{D}$ & $766 \mathrm{~A}$ & $766 \mathrm{~A}$ & $766 \mathrm{~A}$ & $766 \mathrm{~A}$ & $766 \mathrm{~A}$ \\
\hline $\begin{array}{l}\text { Core- } \\
\text { section }\end{array}$ & $63 \mathrm{R}-01$ & 01R-01 & $07 \mathrm{R}-02$ & $13 \mathrm{R}-03$ & $15 \mathrm{R}-02$ & $16 \mathrm{R}-01$ & $18 \mathrm{R}-01$ & $19 \mathrm{R}-01$ & $19 \mathrm{R}-02$ & $22 \mathrm{R}-01$ & 23R-01 & $48 \mathrm{R}-07$ & $49 \mathrm{R}-04$ & 53R-03 & $55 \mathrm{R}-02$ & 55R-03 \\
\hline $\begin{array}{l}\text { Interval } \\
(\mathrm{cm})\end{array}$ & $122-124$ & $094-096$ & 009-011 & $019-021$ & 014-017 & $039-041$ & $112-114$ & $072-078$ & $032-034$ & $118-121$ & $062-064$ & $025-027$ & $106-108$ & 091-093 & $074-076$ & $105-118$ \\
\hline $\mathrm{La}$ & 2.2 & 2.1 & 2.1 & 1.9 & 2.1 & 1.3 & 2.2 & 2.7 & 2.7 & 2.0 & 2.4 & 5.2 & 1.7 & 3.2 & 2.7 & 2.8 \\
\hline $\mathrm{Ce}$ & 7 & 8 & 7 & 5 & 9 & 6 & 7 & 10 & 9 & 7 & 7 & 18 & 6 & 11 & 9 & 9 \\
\hline $\mathrm{Nd}$ & 7 & 8 & 8 & 6 & 9 & 6 & 8 & 9 & 9 & 8 & 6 & 15 & 6 & 10 & 9 & 9 \\
\hline $\mathrm{Sm}$ & 3.23 & 2.98 & 3.07 & 2.17 & 3.24 & 1.90 & 3.18 & 3.48 & 3.84 & 2.67 & 2.63 & 5.22 & 2.23 & 4.14 & 3.20 & 3.65 \\
\hline Eu & 1.10 & 1.03 & 1.06 & 0.84 & 1.10 & 0.62 & 1.12 & 1.24 & 1.30 & 0.96 & 0.97 & 1.72 & 0.89 & 1.31 & 1.13 & 1.25 \\
\hline $\mathrm{Tb}$ & 0.9 & 0.8 & 0.9 & 0.6 & 0.8 & & 0.9 & 1.1 & & 0.8 & 0.7 & & & 1.1 & 0.9 & \\
\hline Ho & 1.4 & 1.4 & 1.3 & 1.0 & 1.4 & 0.8 & 1.5 & 1.9 & 1.7 & 1.2 & 1.1 & 1.8 & 1.0 & 1.8 & & 1.8 \\
\hline $\mathrm{Tm}$ & & 0.5 & 0.5 & 0.4 & & & 0.6 & & & 0.5 & & & & & & \\
\hline $\mathrm{Yb}$ & 4.1 & 3.6 & 3.7 & 2.9 & 3.9 & 2.3 & 3.9 & 4.6 & 4.7 & 3.5 & 3.3 & 5.3 & 3.0 & 5.6 & 4.7 & 5.0 \\
\hline $\mathrm{Lu}$ & 0.59 & 0.60 & 0.55 & 0.44 & 0.66 & 0.42 & 0.60 & 0.66 & 0.68 & 0.50 & 0.56 & 0.80 & 0.49 & 0.90 & 0.73 & 0.81 \\
\hline $\mathrm{Sc}$ & 46.63 & 47.86 & 46.56 & & 45.5 & 35.5 & 47.23 & 47.99 & 48.1 & 45.22 & 46.5 & 61.2 & 52.56 & 51.37 & 49.3 & 49.4 \\
\hline Hf & 2.9 & 2.5 & 2.3 & 2 & 3.2 & 2.3 & 2.8 & 2.9 & 3.4 & 2.1 & 2.2 & 5.4 & 1.8 & 3.7 & 2.8 & 3.2 \\
\hline $\mathrm{Ta}$ & 2.4 & 1.3 & 1.8 & 0.92 & 1.9 & 0.28 & 1 & 1.8 & 3.3 & 0.7 & 1.1 & 1.2 & 2.3 & 1.5 & 1.9 & 1.5 \\
\hline $\mathrm{Th}$ & 0.3 & 0.3 & 0.3 & 0.5 & 0.3 & & 0.5 & 0.5 & 0.4 & 0.3 & 0.6 & 0.8 & & 0.6 & 0.2 & 0.5 \\
\hline $\mathrm{U}$ & 0.19 & 0.11 & 0.15 & 0.14 & 0.2 & 0.16 & 0.13 & 0.14 & 0.7 & 0.11 & 0.6 & 0.3 & 0.2 & 0.5 & 0.16 & 0.2 \\
\hline
\end{tabular}

Table 2: $\mathrm{Sr}$, Nd and $\mathrm{Pb}$ Isotope Data for Basalts from Site 765,

\begin{tabular}{|c|c|c|c|c|c|c|}
\hline Sample & & $87 \mathrm{Sr} / 86 \mathrm{Sr}$ & $143 \mathrm{Nd} / 144 \mathrm{Nd}$ & $\begin{array}{l}206 \mathrm{~Pb} / \\
204 \mathrm{~Pb}\end{array}$ & $\begin{array}{l}207 \mathrm{~Pb} / \\
204 \mathrm{~Pb}\end{array}$ & $\begin{array}{l}208 \mathrm{~Pb} / \\
204 \mathrm{~Pb}\end{array}$ \\
\hline $\begin{array}{c}765 \mathrm{C} 063 \mathrm{R}-01 \\
098-102\end{array}$ & Glass & $0.70299+1-3$ & & & & \\
\hline $\begin{array}{c}\text { 765D 005R-01 } \\
053-056\end{array}$ & Glass & $0.70294+1.4$ & & 18.062 & 15.548 & 37.886 \\
\hline $\begin{array}{c}65 \mathrm{D} 024 \mathrm{R}-03 \\
098-104\end{array}$ & Glass & $0.70277+/-3$ & & 18.178 & 15.651 & 38.111 \\
\hline $\begin{array}{c}765 \mathrm{C} 063 \mathrm{R}-01 \\
122-124\end{array}$ & WR & & & 18.184 & 15.418 & 37.528 \\
\hline $\begin{array}{c}\text { 765D 001R-01 } \\
094-096\end{array}$ & WR & & $0.51309+1-2$ & 18.121 & 15.490 & 37.680 \\
\hline $\begin{array}{c}765 \mathrm{D} 013 \mathrm{R}-01 \\
019-021\end{array}$ & WR & & & 18.415 & 15.448 & 37.397 \\
\hline $\begin{array}{c}\text { 765D 027R-02 } \\
096-098\end{array}$ & WR & & $0.51309+/-1$ & 18.119 & 15.502 & 37.781 \\
\hline
\end{tabular}

samples because seawater contamination was considered negligible.

\section{Geochemistry of Volcanic Rocks from Sites $\mathbf{7 6 5}$ and $\mathbf{7 6 6}$}

The general petrological and geochemical characteristics of the lavas are presented by Ishiwatari (this volume). Both sites are characterized by relatively Fe-rich tholeiites having trace-element characteristics typical of normal mid-ocean ridge basalts (NMORB). In general, samples from Site 766 have higher $\mathrm{TiO}_{2}$, total- $\mathrm{FeO}$, and $\mathrm{Zr}$ contents than those from Site 765 , indicating a more fractionated composition. $\mathrm{FeO}$ contents are $>10 \mathrm{wt} \%$ for all samples, while the most evolved sample from Site 766 (Sample 123-766A-48R-7, 25-27 cm) has a total FeO content of $15.7 \mathrm{wt} \%$; $\mathrm{TiO}_{2}$ of $2.79 \mathrm{wt} \%$; and $\mathrm{Zr}$ of $168 \mathrm{ppm}$, approaching the compositions of Fe-Ti MORBs from the East Pacific Rise (Perfitt et al., 1983). In both sites, total $\mathrm{FeO}$ contents are greater than those of MIORBs (Fig. 3).

Downhole variation in degree of fractional crystallization was observed for Site 765. This is demonstrated in Figure 4, where $\mathrm{Zr}$ and $\mathrm{TiO}_{2}$ contents are plotted relative to stratigraphy. A distinct cyclicity for these elements can be observed, while the $\mathrm{TiO}_{2} / \mathrm{Zr}$ values remain constant. These variations can be explained in terms of low-pressure fractionation of the phases observed within the basalts. The results of a simple least-squares mixing calculation (Bryan et al., 1969) are presented in Table 3. The variation in major elements can be explained by crystal fractionation of plagioclase and clinopyroxene in approximately equal proportions. Note that olivine is not observed as a phenocryst phase in these basalts and that they represent evolved compositions that might reasonably crystallize clinopyroxene. To achieve a realistic solution to the model, one must remove an oxide phase. In most variation diagrams, total $\mathrm{FeO}$ does not display the enrichment trend typical of less-evolved tholeiites (Ishiwatari, this volume). In fact, $\mathrm{FeO} / \mathrm{MgO}$ values in basaltic glasses from this site display a subtle negative correlation with $\mathrm{TiO}_{2}$ (the opposite of what one might expect to result from gabbroic fractionation). Ishiwatari interprets this variation as reflecting source heterogeneity in $\mathrm{FeO} / \mathrm{MgO}$ for the Site 765 basalts.

The REE fractionation exhibited by the Leg 123 lavas is shown in Figure 5. Patterns for the samples from Sites 765 and 766 are depleted with $(\mathrm{La} / \mathrm{Sm})_{n}$, which ranges from low values of 0.5 to 0.7 ; the lavas are characterized by well-developed Eu anomalies. The profiles display a parallel evolution, which is coupled with increasing $\mathrm{Zr}$ and other incompatible trace elements. These data are consistent with the results of the fractionation calculations (Table 3) that indicate a low-pressure fractionation process involving approximately $30 \%$ extraction of plagioclase and clinopyroxene. The samples from Site 766 exhibit similar LREE depletion, but have higher total REE values in the most evolved samples; again, this is consistent with highly fractionated MORB magma.

Given the relatively minor variation in REE fractionation and constant ratios for $\mathrm{Zr}$, REEs, and $\mathrm{Nb}$, source heterogeneity is probably of minor importance for generating the geochemical trends displayed by the Site 765 and 766 lavas. The somewhat ambiguous geochemical trends displayed by the lavas (Ishiwatari, this volume; Ludden, Gradstein, et al., 1990) are more likely the consequence of a fractionating basaltic magma that was "hungup" on its low-pressure cotectic.

\section{Geochemistry of Leg 123 Lavas Relative to MIOR and Red Sea Rift Lavas}

Despite the effects of low-pressure fractionation, the most mafic lavas at Site 765 are easily identifiable, and one can project approximate fractionation trajectories. At Site 765 , a value of 

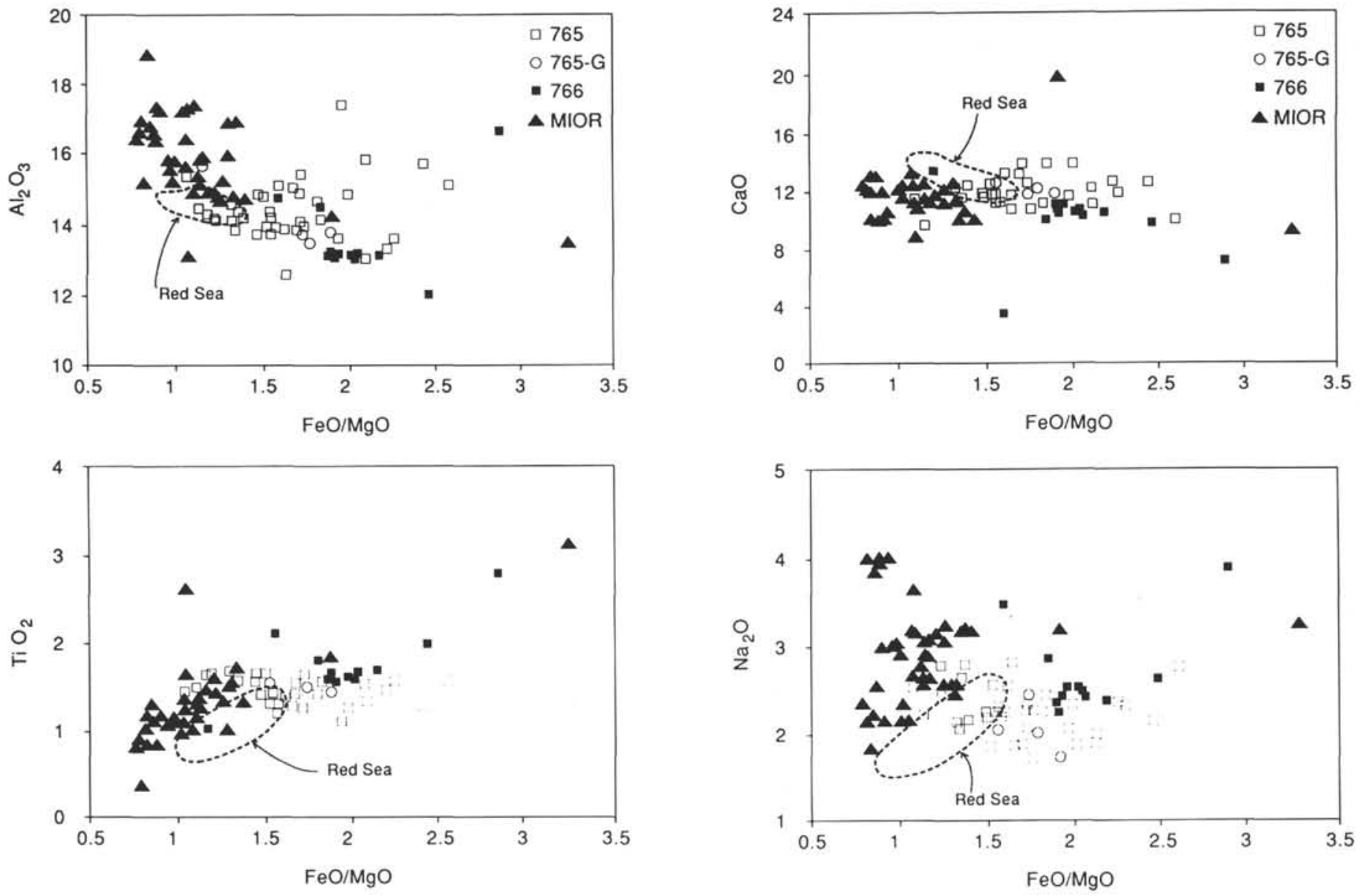

Figure 3. Comparisons of the geochemistry of Site 765 and 766 magmas with the range in compositions from the MIOR. Data for MIOR from Frey et al. (1977); Price et al. (1986); Dosso et al. (1988); Humler and Whitechurch (1988). Fields for Red Sea rift are from glass analyses provided in Eissen et al. (1989).

Table 3. Leg 123 Site 765, Fractional crystallisation model.

\begin{tabular}{lrrrrrrrrr}
\hline \multicolumn{2}{l}{ Most primitive to most evolved basalt } \\
\hline $\mathrm{SiO}_{2}$ & $\mathrm{Al}_{2} \mathrm{O}_{3}$ & $\mathrm{FeO}_{t}$ & \multicolumn{1}{l}{$\mathrm{MgO}$} & $\mathrm{CaO}$ & $\mathrm{Na}_{2} \mathrm{O}$ & $\mathrm{TiO}_{2}$ & $\mathrm{~K}_{2} \mathrm{O}$ & Factor \\
\hline Product & 51.07 & 13.96 & 11.70 & 7.28 & 11.31 & 2.59 & 1.66 & 0.30 & 76.5 \\
$\mathrm{CPX}$ & 52.76 & 3.31 & 5.10 & 18.50 & 19.90 & 0.02 & 0.27 & 0.15 & 10.0 \\
PLAG & 45.00 & 35.00 & 0.00 & 0.00 & 18.50 & 1.50 & 0.00 & 0.00 & 12.5 \\
$\mathrm{MT}$ & 0.00 & 0.00 & 99.99 & 0.00 & 0.00 & 0.00 & 0.00 & 0.00 & 1.5 \\
Parent & 50.05 & 15.27 & 10.95 & 7.13 & 13.11 & 2.01 & 1.25 & 0.25 & \\
Result & 49.99 & 15.41 & 10.95 & 7.25 & 13.01 & 2.12 & 1.31 & 0.25 & \\
Difference & -0.06 & 0.14 & 0.01 & 0.08 & -0.10 & 0.12 & 0.06 & 0.02 & \\
\hline
\end{tabular}

\begin{tabular}{cccc}
\hline & Parent & Product & Factor \\
\hline $\mathrm{Zr}$ & $(\mathrm{ppm})$ & $(\mathrm{ppm})$ & $(\mathrm{ppm})$ \\
$\mathrm{Y}$ & 30 & 95 & 1.35 \\
$\mathrm{Yb}$ & 1.8 & 42 & 1.40 \\
$\mathrm{La}$ & 2.0 & 2.7 & 1.39 \\
$\mathrm{Sm}$ & 2.7 & 3.8 & 1.35 \\
$\mathrm{Yb}$ & 3.5 & 4.7 & 1.40 \\
$\mathrm{Hf}$ & 2.3 & 3.4 & 1.47 \\
$\mathrm{Ni}$ & 80 & 70 & 0.85 \\
$\mathrm{Cr}$ & 210 & 180 & 0.85 \\
\hline
\end{tabular}

approximately $1.2 \mathrm{wt} \% \mathrm{TiO}_{2}$ is equivalent to $8 \mathrm{wt} \% \mathrm{MgO}$. Relative to other MORBs, the Site 765 magmas are rich in $\mathrm{CaO}$ (approximately 13.5-14.0 wt\%) and $\mathrm{FeO}$ (approximately 9.5$10.5 \mathrm{wt} \%$ ), and poor in $\mathrm{Na}_{2} \mathrm{O}$ (approximately $1.8-2.0 \mathrm{wt} \%$ ) and $\mathrm{Al}_{2} \mathrm{O}_{3}$ (approximately $13 \mathrm{wt} \%$ ). For trace elements, the Leg 123 lavas are poor in $\mathrm{Zr}(65-70 \mathrm{ppm})$ and $\mathrm{La}$ (approximately $2.0 \mathrm{ppm}$ ). These characteristics are exemplified in Figure 3, where the Leg 123 lavas (in particular those from Site 765 ) project to $\mathrm{CaO}$-rich and $\mathrm{Na}_{2} \mathrm{O}$-poor compositions.

Glass analyses for the Red Sea rift (Eissen et al., 1989) are shown as a field in Figure 3. In terms of $\mathrm{CaO}, \mathrm{Na}_{2} \mathrm{O}, \mathrm{TiO}_{2}$, and $\mathrm{Al}_{2} \mathrm{O}_{3}$, the Red Sea lavas overlap with and/or trend toward the compositions defined by the Leg 123 lavas and are also distinct from lavas from the MIOR and the Mid-Atlantic Ridge, as demonstrated by Eissen et al. (1989).

One of the most important characteristics of the Leg 123 lavas is their high degree of LREE depletion (Fig. 5). The degree of depletion is comparable to, or slightly greater than, that of the most primitive samples from the Red Sea rift (Fig. 5). In general, with rare exceptions, primitive samples from modern MIORs are characterized by $(\mathrm{La} / \mathrm{Sm})_{\mathrm{n}}$ values of approximately 0.7 to 0.9 (Dosso et al., 1988; Price et al., 1986). Similarly, Mid-Atlantic Ridge basalts in the $22^{\circ}$ to $27^{\circ}$ regions have $(\mathrm{La} / \mathrm{Sm})_{n}$ values greater than 0.7. Notable exceptions are from areas of thick 


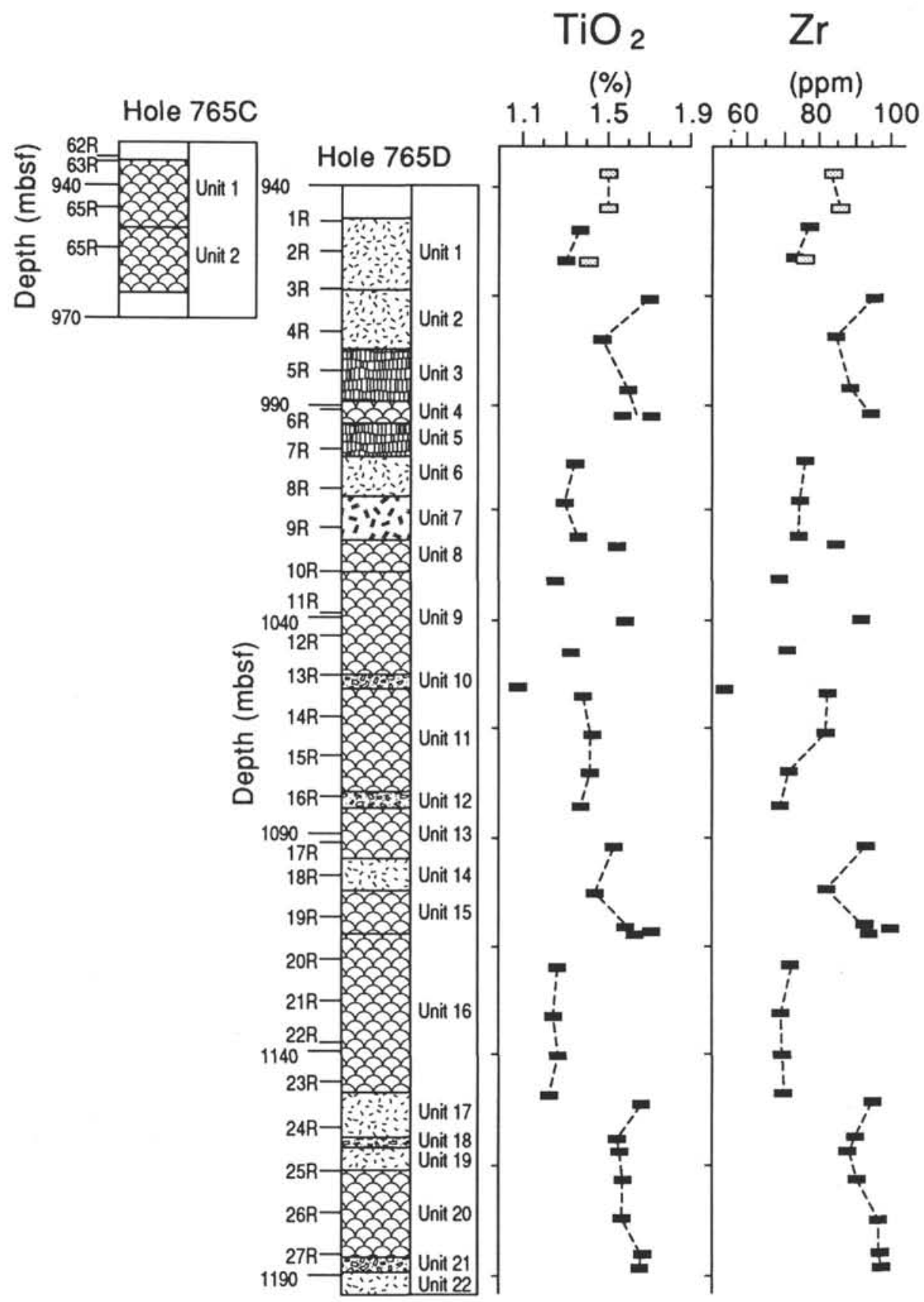

Figure 4. Downhole variation in $\mathrm{TiO}_{2}$ and $\mathrm{Zr}$ abundances for Site 765 lavas.

oceanic crust (shallow water depths) of the Koblenski Ridge (Schilling et al., 1983).

\section{Isotope Composition of Jurassic MORB From the Indian Ocean}

In Figure 6, the ${ }^{143 / 144} \mathrm{Nd}$ and ${ }^{206 / 204} \mathrm{~Pb}$ results from the Site 765 basalts have been compared to samples from the MIOR and oceanic islands. As demonstrated by Ito et al. (1987) and Klein et al. (1988), the MIORB reservoir is distinct from that supplying basalts that erupted at ridge axes in the Atlantic and Pacific oceans. This is best demonstrated in the ${ }^{143 / 144} \mathrm{Nd}$ and ${ }^{206 / 204} \mathrm{~Pb}$ diagram, as the database for the two oceans is most differentiated in terms of these isotopes. The Leg 123 data fall within the modern MIOR field, indicating that the Indian Ocean mantle reservoir was characterized by distinct composition at $150 \mathrm{Ma}$ and that the
"Dupal" anomaly (Hart, 1984) is not a recent feature on Earth. The Red Sea basalts fall within the limit of the Indian Ocean and Atlantic-Pacific domains and are geographically at the limit of the Dupal domain defined by Hart (1984).

\section{DISCUSSION}

\section{Geochemical Characteristics of Magmas at the Onset of Oceanic Rifting}

Both the Red Sea basalts and the Leg 123 basalts were formed near the continental margin at the onset of rifting in the Indian Ocean. The Red Sea represents crust formed by the melting of Indian Ocean mantle since the last $3 \mathrm{Ma}$ (Eissen et al., 1989). Site 765 basaltic crust, on the other hand, formed from Indian Ocean 

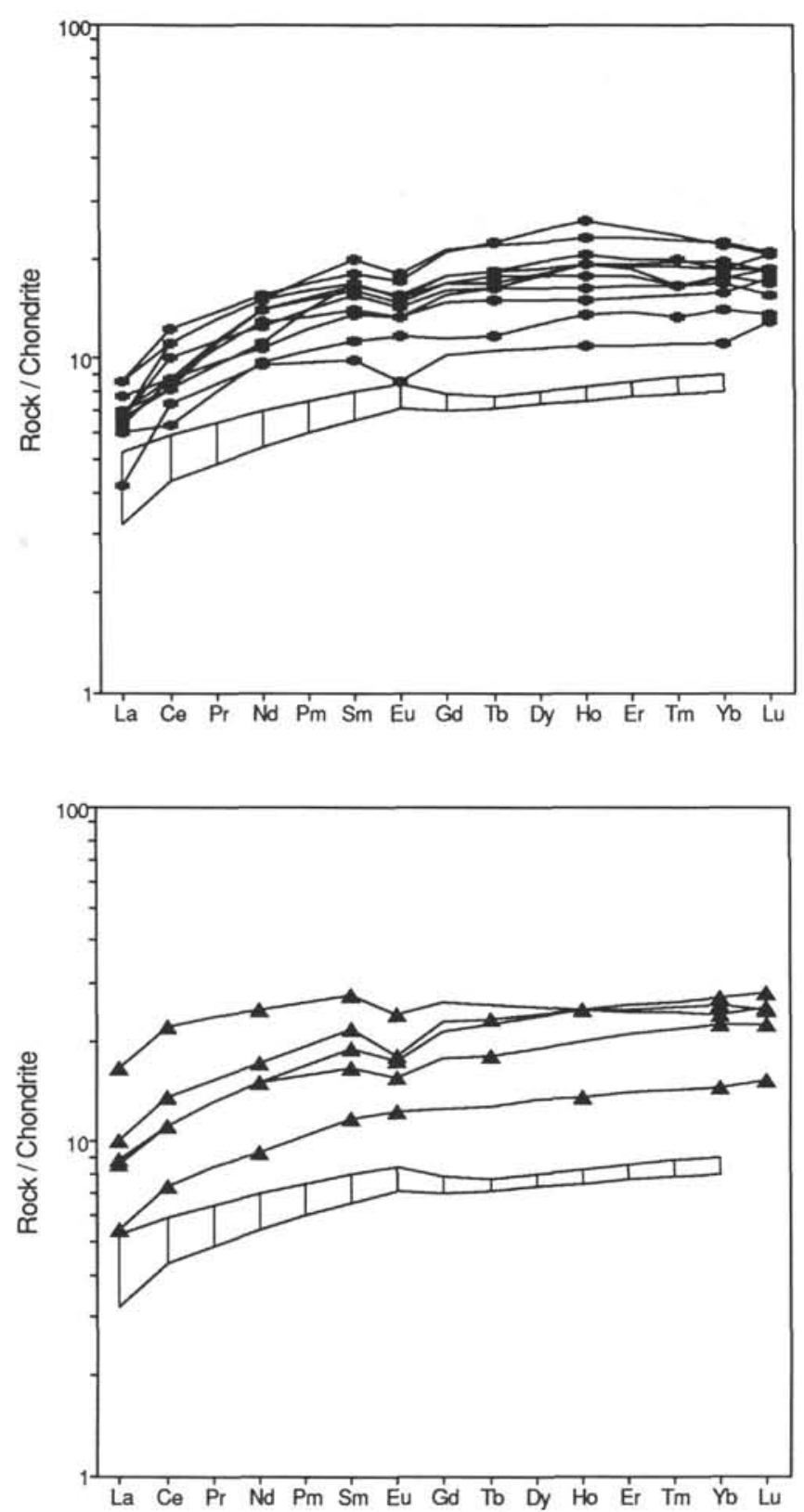

Figure 5. Chondrite-normalized REE plots for lavas from Sites 765 (upper diagram) and 766 (lower diagram). Red Sea samples field from Eissen et al. (1989).

mantle about $155 \mathrm{Ma}$ ago. In both cases, the tectonic environment is that of a recently formed oceanic basin, with thinned continental crust in close proximity and with a significant mantle thermal anomaly associated with the rifting process. Despite the presence of these thermal plumes (the Afar hot spot for the Red Sea and the hot spot that erupted the mafic plateaus represented in Fig. 1 for the northwestern Australian margin), the basalts that erupted at both sites are LREE-depleted MORBs having geochemical characteristics that are generally distinct from those of MORBs that erupted in mature ocean basins (i.e., the Central Mid-Indian Ocean Ridge, the East Pacific Rise, and the Mid-Atlantic Ridge). In terms of major elements, the magmas are high in $\mathrm{CaO}$ and $\mathrm{FeO}$ and low in $\mathrm{Na}_{2} \mathrm{O}$ and $\mathrm{Al}_{2} \mathrm{O}_{3}$, relative to MORBs that erupted in the Central Indian Ocean ridges. In addition, these lavas have low $(\mathrm{La} / \mathrm{Sm})_{\mathrm{n}}$ and low incompatible trace elements (such as $\mathrm{Zr}$ and
$\mathrm{Nb}$ ), relative to MIORs and other MORBs that erupted in mature ocean basins. All of these characteristics reflect the great extent of mantle melting that might be expected to characterize a hot oceanic mantle at the onset of oceanic rifting (cf. Klein and Langmuir, 1987). Keen et al. (1990) suggested that such geochemical characteristics are typical of old oceanic crust in all oceanic basins. Their data were based on a correlation of geochemistry with depths to oceanic basement defined from seismic backtracking calculations; the depth indicated for Site 765 is approximately $2.5 \mathrm{~km}$. Both the Red Sea and Leg 123 data indicate that the Indian Ocean mantle was hotter at the inception of oceanic rifting, while the ridges that are distant to the continental margins, in general, were formed over a cooler mantle, with the consequent differences in basalt geochemistry and thickness of oceanic crust.

\section{Isotope Evolution of the Indian Ocean MORB Reservoir}

As demonstrated in Figure 6, Jurassic Indian Ocean mantle was similar in isotopic character to the mantle now being sampled at the MIOR. Its distinctive character must pre-date the formation of the present Indian Ocean. Paleomagnetic data indicate that Site 765 was erupted at approximately $30^{\circ} \mathrm{N}(\mathrm{Ogg}$, this volume). Hart (1984) suggested that the Dupal characteristics of the Indian Ocean have a prolonged history in the Earth (possibly as much as $1700 \mathrm{Ma}$ ) and that these anomalies represent material having continental characteristics that was reinjected into the mantle during the mid-Proterozoic. The Leg 123 results indicate that this material was available in the upper Indian Ocean mantle at the onset of rifting; the transfer of the Dupal-type mantle into the MORB reservoir therefore must either have pre-dated rifting of the Indian Ocean or may be a general characteristic of the Indian Ocean MORB reservoir.

\section{CONCLUSIONS}

Basalts at Site 765 and Site 766 were erupted on the northwestern continental margin at the onset of rifting of the Indian Ocean at $155 \mathrm{Ma}$. They are LREE-depleted MORBs that are characterized by higher $\mathrm{CaO}$ and $\mathrm{FeO}$ and lower $\mathrm{Na}_{2} \mathrm{O}, \mathrm{Al}_{2} \mathrm{O}_{3},(\mathrm{La} / \mathrm{Sm})_{n}$ and incompatible trace elements than basalts erupted at the present MIOR. They share many geochemical similarities to tholeiitic basalts of the Red Sea rift. Both Site 765 and the Red Sea basalts were formed at the onset of rifting of the Indian Ocean at $155 \mathrm{Ma}$ and 3 to $5 \mathrm{Ma}$, respectively. The geochemical characteristics of both regions reflect high-degrees of melting of the oceanic mantle that may be related to the enhanced thermal regime characteristic of the initial stages of continent to oceanic rifting. In the case of the Red Sea, the thermal anomaly is reflected by the presence of the Afar hot spot and for the northwestern Australian margin by extensive plateaus of volcanic rocks that were formed at the time of continental break-up (160-130 Ma). The geochemi$\mathrm{cal}$ characteristics recognized for the Red Sea and Sites 765 and 766 may be applicable generally to oceanic crust formed at the onset of rifting.

Isotopic characteristics of Jurassic MORB were similar to those of MORB currently being erupted in the Indian Ocean. In both cases, the basalts are isotopically distinct from those erupted in the Atlantic and Pacific oceans, indicating that the source of Indian Ocean MORB was of Dupal composition from the onset of spreading.

\section{ACKNOWLEDGMENTS}

We thank Terry Plank for her interest in and advice about the Leg 123 Ocean Drilling Program. We thank Alan Smith (University of Alberta) and C. Gariepy (UQAM, Quebec) for their help in obtaining the isotope data. Gilles Gauthier (Université de Montréal) provided the REE analyses. This research was sup- 


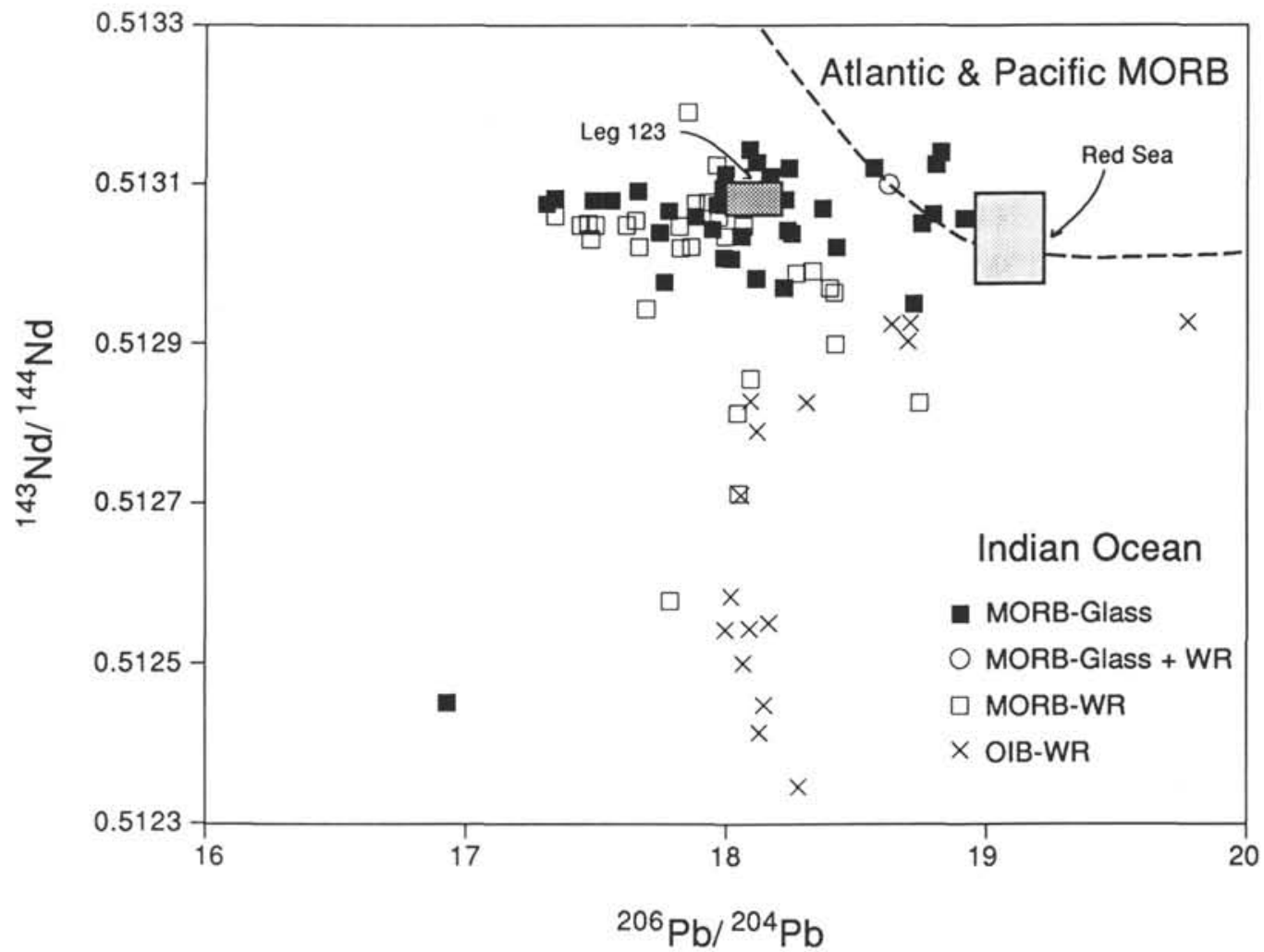

Figure 6. ${ }^{143} \mathrm{Nd} /{ }^{144} \mathrm{Nd}$ and ${ }^{206} \mathrm{~Pb} /{ }^{204} \mathrm{~Pb}$ variations for lavas from the ridge axes of the Indian Ocean. Leg 123 Jurassic basalts and Red Sea basalts indicated by shaded boxes. Indian Ocean data from following sources: Cohen et al. (1980, 1982); Dosso et al. (1979, 1980, 1988); Eissen et al. (1989); Hamelin and Allègre (1985); Hamelin et al. (1985); Ito et al. (1986); Klein et al. (1988); Michard et al. (1986); Price et al. (1986); Roden et al. (1984); Storey et al. (1988).

ported by an NSERC collaborative special project grant to J. N. Ludden.

\section{REFERENCES}

Bryan, W. B., Finger, L., and Chayes, F., 1969. Estimating proportions in petrographic mixing equations by least squares approximations. Science, 163:926-927.

Campbell, I. H., and Griffiths, R. W., 1990. Implications of mantle plume structure for the evolution of flood basalts. Earth Planet. Sci. Lett. 99:79-93.

Cohen, R. S., Evensen, N. M., Hamilton, P. J., 1980. U-Pb, Sm-Nd and $\mathrm{Rb}-\mathrm{Sr}$ systematics of mid-ocean ridge basalt glasses. Nature, 283: 149-153.

Cohen, R. S., and O'Nions, R. K., 1982. The lead, neodynium and strontium isotopic structure of ocean ridge basalts. J. Petrol., 23:299324.

Dick, H.J.B., and Fisher, R. L., 1984. Mineralogical studies of the resuidues of partial melting: abyssal- and alpine-type peridotites. In Kornprobst, J. (Ed.), Kimberlites II: The Mantle and Crust-Mantle Relationships. Devel. in Petrol. Ser. Amsterdam (Elsevier), 295-308.

Dosso, L., Bougault, H., Beuzart, P., Calvez, J.-Y., and Joron, J.-L., 1988. The geochemical structure of the South-East Indian Ridge. Earth Planet. Sci. Lett., 88:47-59.

Dosso, L., and Murthy, V. R., 1980. A Nd isotopic study of the Kerguelen Islands: inferences on enriched oceanic mantle sources. Earth Planet. Sci. Lett., 48:268-276.

Dosso, L., Vidal, P., Cantagrel, J. M., Lameyre, J., Marot, A., and Zimine, S., 1979. "Kerguelen: Continental fragment or oceanic island?": petrology and isotopic geochemistry evidence. Earth Planet. Sci. Lett., 43:46-60.

Dupré, B., and Allègre, C. J., 1980. Pb-Sr-Nd isotopic correlation and the chemistry of the North Atlantic mantle. Nature, 286:17-22.
Eissen, J.-P., Juteau, T., Joron, J.-L., Dupré, B., Humler, E., and Al'Mukhamedov, A., 1989. Petrology and geochemistry of basalts from the Red Sea Axial Rift at $18^{\circ}$ North. J. Petrol., 30:791-839.

Frey, F. A., Dickey, J. S., Thompson, G., and Bryan, W. B., 1977. Eastern Indian Ocean DSDP sites: correlations between petrography, geochemistry and tectonic setting. In Heirtzler, J. R., Bolli, H. M., Davies, T. A., Saunders, J. B., and Sclater, J. G. (Eds.), A Synthesis of Deep Sea Drilling in the Indian Ocean. Washington (U.S. Govt. Printing Office), $189-257$.

Hamelin, B., and Allègre, C. J., 1985. Large-scale regional units in the depleted upper mantle revealed by an isotope study of the South-West Indian Ridge. Nature, 315:196-199.

Hamelin, B., Dupré, B., and Allègre, C. J., 1985. Pb-Sr-Nd isotopic data of Indian Ocean ridges: new evidence of large-scale mapping of mantle heterogeneities. Earth Planet. Sci. Lett., 76:288-298.

Hart, S. R., 1984. A large scale isotopic anomaly in the Southern Hemisphere mantle. Nature, 309:753-757.

Hart, S. R., and Brooks, C., 1977. The geochemistry and evaluation of early Precambrian mantle. Contrib. Mineral. Petrol., 61:109-128.

Humler, E., and Whitechurch, H., 1988. Petrology of basalts from the Central Indian Ridge (lat. $25^{\circ} 23^{\prime} \mathrm{S}$, long. $70^{\circ} 04^{\prime} \mathrm{E}$ ): estimates of frequencies and fractional volumes of magma injection in a two layered reservoir. Earth Planet. Sci. Lett., 88:169-181.

Ito, E., White, W. M., and Gopel, C., 1987. The O, Sr, Nd and Pb isotope geochemistry of MORB. Chem. Geol., 62:157-176.

Keen, M. J., Klein, E. M., and Melson, W. G., 1990. Ocean-ridge basalt compositions correlated with paleobathymetry. Nature, 345:423-426.

Klein, E. M., and Langmuir, C. H., 1987. Global correlations of ocean ridge basalt chemistry with axial depth and crustal thickness. $J$. Geophys. Res., 92:8089-8115.

1989. Local versus global variations in ocean ridge basalt composition: a reply. J. Geophys. Res., 94:4241-4252. 
Klein, E. M., Langmuir, C. H., Zindler, A., Staudigel, H., and Hamelin, B., 1988. Isotope evidence of a mantle convection boundary at the Australian-Antarctic Discordance. Nature, 333:623-629.

Ludden, J. N., Gradstein, F. M., et al., 1990. Proc. ODP, Init. Repts., 123: College Station, TX (Ocean Drilling Program).

Manhès, G., Minster, J.-F., and Allègre, C.-J., 1978. Comparative uranium-thorium-lead and rubidium-strontium of St. Severin amphoterite: consequences for early solar system chronology. Earth Planet. Sci. Lett., 39:14-24.

McKenzie, D., and Bickle, M. J., 1988. The volume and composition of melt generated by extension of the lithosphere.J.Petrol., 29:625-679.

Michard, A., Montigny, R., and Schlich, R., 1986. Geochemistry of the mantle beneath the Rodriguez triple junction and the South-East Indian Ridge. Earth Planet. Sci. Lett., 78:104-114.

Mutter, J. C., Buck, W. R., and Zehnder, C. M., 1988. Convective partial melting. 1. A model for the formation of thick basaltic sequences during the initiation of spreading. J. Geophys. Res., 93:1031-1048.

Perfit, M. R., Fornari, D. J., Malahoff, A., and Embley, R. W., 1983. Geochemical studies of abyssal lavas recovered by DSRV Alvin from eastern Galapagos Rift, Inca Transform and Ecuador Rift. 3. Trace element abundances and petrogenesis. J. Geophys. Res., 88:1055110572.

Price, R. C., Kennedy, A. K., Riggs-Sneeringer, M., and Frey, F. A., 1986. Geochemistry of basalts from the Indian Ocean triple junction: implications for the generation and evolution of Indian Ocean ridge basalts. Earth Planet. Sci. Lett., 78:379-396.

Roden, M. K., Hart, S. R., Frey, F. A., and Melson, W. G., 1984. Sr, Nd and $\mathrm{Pb}$ isotopic and REE geochemistry of St-Paul's rocks: the metamorphic and metasomatic development of an alkali basalt mantle source. Contrib. Mineral. Petrol., 85:376-390.
Schilling, J.-G., Zajac, M., Evans, R., Johnson, T., White, W., Devine, J. D., and Kingsley., R., 1983. Petrologic and geochemical variations along the mid-Atlantic ridge from $29^{\circ} \mathrm{N}$ to $75^{\circ} \mathrm{N}$. Am. J.Sci, , 283:510586.

Storey, M., Saunders, A. D., Tarney, J., Leat, P., Thirlwall, M. F., Thompson, R. N., Menzies, M. A., and Marriner, G. F., 1988. Geochemical evidence for plume-mantle interactions beneath Kerguelen and Heard Islands, Indian Ocean. Nature, 336:371-374.

Veevers, J. J., and Cotterill, D., 1978. Western margin of Australia: evolution of rifted arch system. Geol. Soc. Am. Bull., 89:337-355.

Veevers, J. J., Tayton, J. W., and Johnson, B. D., 1985. Prominent magnetic anomaly along the continent/ocean boundary between the northwestern margin of Australia (Exmouth and Scott plateaus) and the Argo Abyssal Plain. Earth Planet. Sci. Lett., 72:415-426.

von Rad, U., and Exon, N. F., 1983. Mesozoic-Cenozoic sedimentary and volcanic evolution of the starved passive continental margin off northwest Australia. In Watkins, J. S., Drake, C. L., and Sheridan, R. E. (Eds.), Studies in Continental Margin Geology: AAPG Mem., 34:253-281.

von Stackelberg, U., Exon, N. F., von Rad, U., Quilty, P., Shafik, S., Beiersdorf, H., Seibertz, E., and Veevers, J. J., 1980. Geology of the Exmouth and Wallaby Plateaus off northwest Australia: sampling of seismic sequences. BMR J. Aust. Geol. Geophys., 5:113-140.

White, R., and McKenzie, D., 1989. Magmatism at Rift Zones: the generation of volcanic continental margins and flood basalts. J. Geophys. Res., 94:7685-7729.

Date of initial receipt: 1 February 1991

Date of acceptance: 29 July 1991

Ms 123B-161 